\title{
Evaluation of the Effectiveness of Education University in a Knowledge-Based Economy
}

\author{
Turcan Aurelia \\ Associate Professor, PHD \\ Vice-Rector, University of European Studies of Moldova \\ aurasofia@mail.ru \\ Sedletsky Nick \\ PhD student \\ University of European Studies of Moldova \\ nick.sedletzki@gmail.com
}

\section{Doi:10.5901/jesr.2013.v3n7p53}

\section{Abstract}

This article analyzes one of the basic elements in building a society based on knowledge - education. But we do the analysis only to a part of it - education, because for the knowledge society is this compartment has a higher valence. Higher education is the driving force of society based on knowledge and has a big influence for Moldova in creation of a society in which the stock of knowledge must occupy an important place in the economy. This problem is strongly influenced by the migration process which, in this particular case, has a negative impact. In this research, we focus on the ability to assess the system of university education with basic statistical indicators. The system of indicators used will allow: the analysis of the human resources of the University Education system; financial resources as an investment in getting a quality education; participation and management education and the internal efficiency of the education system. Also we calculate performance indicators that will enable us to calculate the effectiveness of university education in the Republic of Moldova.

Keywords: university education, society based on knowledge, evaluation education system, the effectiveness of university education, statistical indicators, management education.

\section{Introduction}

The creation of a new society - society of knowledge is a process driven by the European Union's Lisbon strategy in 2000. As a goal it was proposed to become the most competitive and dynamic knowledge-based economy, capable of sustainable growth with more and better jobs and greater social cohesion. This process was based on other acts including the Charter of the Bologna, adopted by the rectors of European universities in September 1998 , which called for the creation of a common European space for higher education. All this generated in most of the continent an intense concern for the improvement of education and raising of its efficiency so that would become the European Union, the most competitive and dynamic society and economy-based-on-knowledge in the world. Based on century- old traditions and urged by the invocations from Bologna and Lisbon, the European universities have joined their forces, constituting themselves into a network of continental organizations aiming to develop a high quality educational system, which will contribute to the dramatic increase of specific parameters of such activity up to the requirements of the new society and of the European nations' desire and expectations.

The higher education, which includes education itself, research and innovation (the " knowledge triangle"), is a key sector in the economy and knowledge society. Thus, it must be competitive and promote the excellence.

To fulfill this aim, is not enough just to invest resources in education and training systems of the Member States. It is necessary to direct and manage them in the most efficient way. The new focus of attention at European level on issues of education and training policy gives a new context to mentioned problems, which refers to three vital elements for the development of a modernized higher education: it must be fair for everyone, financially viable and to play a more effective role. 


\section{Findings and discussion}

\subsection{University system ability}

Including even educational system, any human activity is a row of resources consumption and effects production. Thus, from this point of view the assessment of human and financial resources is very important, because the efficiency of production involves the need to save the social work, as a condition of creating a competitive knowledge-based society.

According to the statements made by all developed countries at the end of XX eth centuries, the demand for higher education has increased significantly.

It has now reached one of the highest levels in the world, and as result all universities from around the world compete to attract students.

The question of Moldovan universities' ability to compete with the best universities in the world, requires from educational system some strict obligations to ensure a high level of constant excellence. But, our universities, in general, have less advantages and financial resources than their counterparts from developed countries. It is also necessary to mention that the dispersion of Moldovan universities is characterized by a remarkable heterogeneity, which is expressed by the ways of organizing, managing, and operating conditions, including the term of status, employment, conditions and selection of teachers and researchers. This dispersion is also confirmed by Webometrics World Ranking which is used for a worldwide evaluation of universities. (Figure 1.), which tents to analyze the quality of universities from our country in 2012 from the total number of higher education institutions (34) included in the top 26 universities from Moldova.

Figure 1. Clasamentului mondial Webometrics.

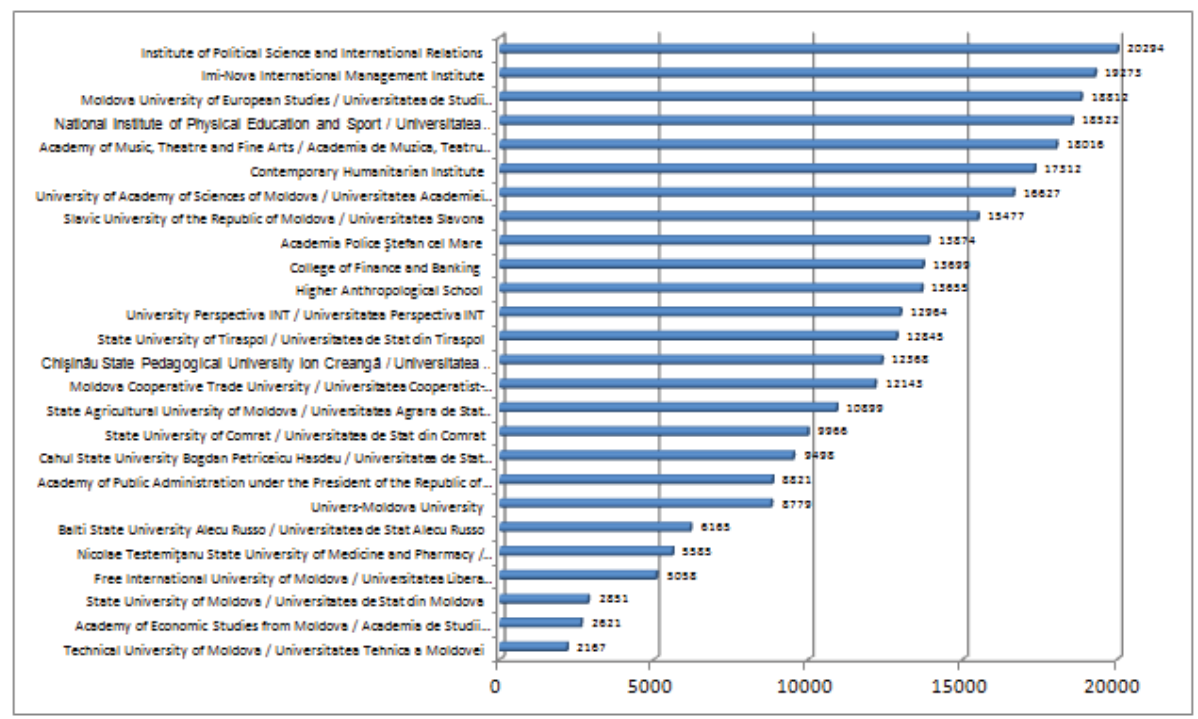

Source: http://www.webometrics.info/en/Europe/Moldova

This world ranking is a positive step towards the improvement of the quality of Moldovan higher education, because only the development of this sector can bring great profits in the future. The competition will increase due to the demand decrease for higher education caused by demographic decline in the country. The lowering of birth rate is an important factor for investments reduction in higher education. But a lot of educational investments are influenced by graduating students' wishes that rely on three main components: education in private or public institutions from the country, education in private or public institutions from abroad and obviously the priority fields of study. Besides, a great influence and popularity comes from the principles gender of study fields.

All these are just some of the issues that the national factors of political decisions have to face in their way of 
searching to expand and diversify the national tertiary education.

\subsection{The higher education financing.}

All higher education funding sources can be grouped into two major categories : public and private funding sources. According to UNESCO information "The public and private investments in education has significantly increased in many OEDC countries during 2009, even the recession has already begun. For example, between 2008 and 2009, the government spending and even the private one (of companies, students and their families) increased at all levels of education in 24 from 31 OECD countries (where statistical information were available). This was noticed even in other 26 countries where the GDP decreased. Similarly, between 2005 and 2009, the spending per pupil in elementary secondary and high schools has increased on average by 15 percent in OECD countries. In this area, the rise in some emerging economies was huge. For example, in Brazil and Russian Federation the spending per pupil and per student has increased by about 60 percent compared to the previous period, remaining, however, much smaller than those from other countries. The expenses per students in tertiary education, in their turn, have increased during the analyzed period with an average of 9 percent. On the other hand, it is less surprising that, while public expenses for education were at the level of $13 \%$ of public spending in OECD countries in 2005 and 2009, today they fallen down in 19 of the 32 countries studied in this period of time." ${ }^{1}$

Despite to the fact of global crisis and the spreading of the global recession in recent years, the desire of developed countries to increase investments in education appears to be very interesting. The significant increase of investments in tertiary education is largely due to the efforts done note only at the State level, but also at the level of private investment. This can be explained only by the fact that the countries have seen the benefits that can be derived from long-term investments.

The share of the educational system ranks Moldova among countries with high spending in this sector.

Figure 2. Share of education in GDP dynamics in the Republic of Moldova, \%

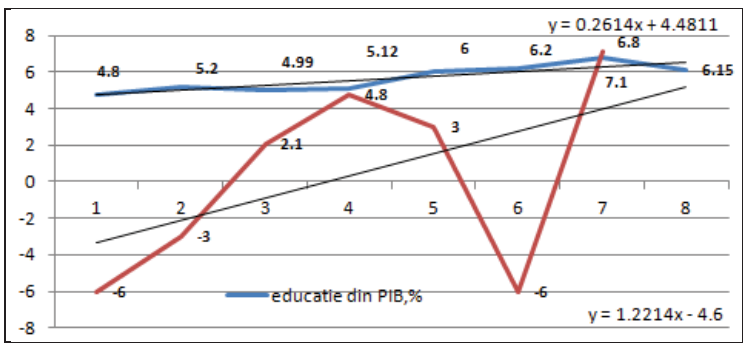

Source: elaborated by the authors according to NBS information.

The share of spending (in current prices) of GDP for education in Moldova for $2010-2011$ is on average 5\%, while the share of tertiary education over the same period is 1.4 and $1.7 \%$ respectively. Internationally the highest values for education are recorded in Iceland - 7.0\%, Denmark - 6.9\%, Sweden - 6\%, U.S. - 5\%, Russia - 4.6\%, Germany - 4\%, Japan $-3.3 \%$. The top countries with the highest expenses for education that encounter between $1.0-1.6 \%$ are considered Denmark, Finland, Canada, Switzerland, France, USA, Russia. While, such developed countries as Germany and Japan spend only $0.9 \%$ and $0.5 \%$.

Perhaps it is necessary to understand how these countries with such small expenses have a so great performance. In this context it should be noted that this area attracts large private investments that probably warrant the level of efficiency and performance. Thus, it is necessary to facilitate the attraction of private funds for the development of tertiary education services, by attracting major investors.

If to compare the share of public investments in higher education of two neighbouring countries as Republic of Moldova and Romania, it can be seen a significant decrease in the share of expenditure in Romania with 3 percent and their growth with 7 percent in the Republic of Moldova, fact that indicates the reduction of State expenditure in supporting the university education.

Figure 3. The comparative dynamics of the share of public expenditure on higher education as $\%$ of GDP 


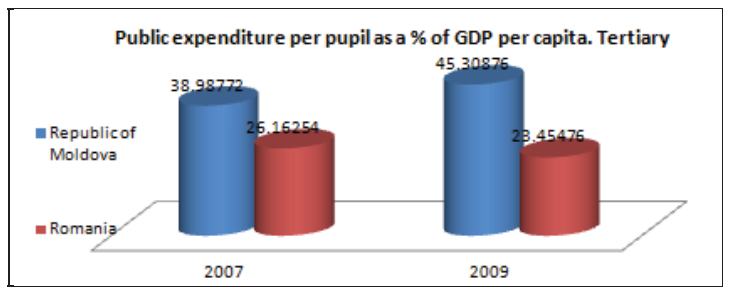

Source: elaborated by the authors according to UNECO

Being in an economic crises combined with prolonged political crises, the Republic of Moldova has big problems in the field of higher education, and the State conveys the burden on the citizens' shoulders. This is confirmed by the increased number of students, who attend classes by contract, amount that reached in the period of academic year $2012 / 13-72,3 \%$. As result, due to the decrease of State investments for higher education, the quota of students in State institutions was reduced, fact that caused the reduction of students number in recent years.

One of the factors that causes the investments' diminution is the slump of birth rates which during the last 30 years (on average 1980-2011) diminished twice and recorded an annual fall of almost 7 thousand births.

Figure 4. The dynamics of birth in the Republic of Moldova for the period of $1980-2011$

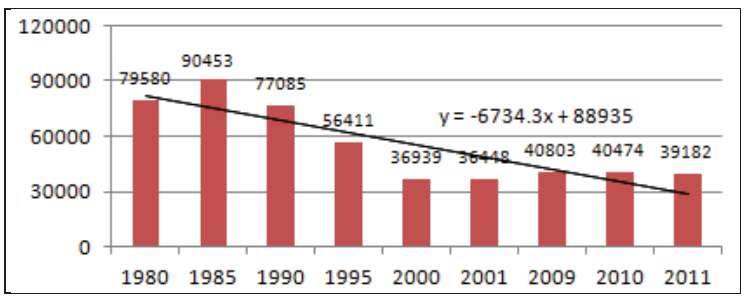

Source: BNS http://statbank.statistica.md/pxweb/Dialog/Saveshow.asp

This situation strongly influences educational system in general, but in the same time it influences the higher education system in particular. Just for the last 7 years the number of students has decreased by over $40 \%$ and the liniar adjustement of this process confirms an annual average decrease of over 7 thousand students annualy.

Figure 4. The dynamics of Moldovan students between the period of $2005-2012$.

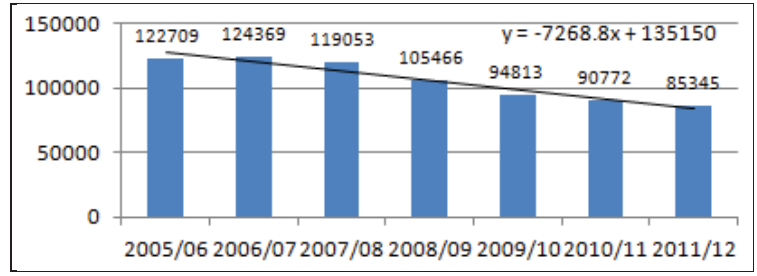

Source: elaborated by the authors according to NBS information.

The correlation between birth and quota of students is obvious.

Analyzing the distribution of students by tertiary education (according to ISCED classification: 5A, 5B, 6) we can conclude that both in Romania and the Republic of Moldova the level $5 \mathrm{~A}$ has a growth in both countries, while the number of those who make their studies in the levels 5B AND 6 is in a constant decrease for each of the cases.

Figure 5. Comparative dynamics of the students classification by levels of tertiary education, $\%$ 


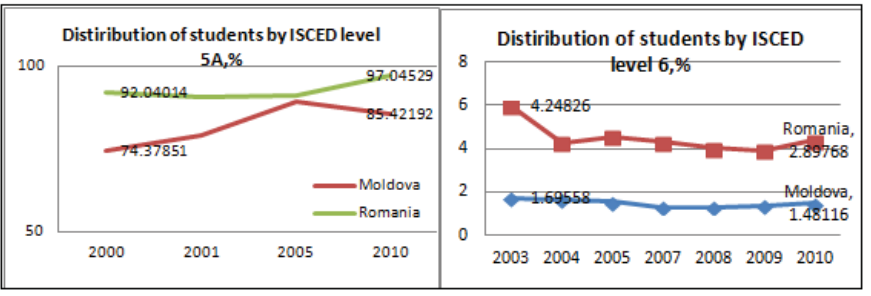

Source: elaborated by the authors according to UNECO

Still, not only the reduction of students' number results the investments decrease in higher education. There is another consequence which is even more alarming. The significant preferences of social sciences whose numbers reached 70 $\%$ in the last years, still this recorded a decrease from 91 thousand to 57 thousand of students.

The studies done at these specialties are mostly by contract. More than $83 \%$ of students who study economy, law, social science, welfare, communication science, do their studies by contract. Another $60 \%$ of students who study exact and natural sciences, engineering sciences, do it for a fee.

On average, the number of students who study by contract in State universities reaches nearly $70 \%$. Only for some specialties the State takes its responsibility in preparing the qualified labour force. These are medicine, agriculture, and military service. Only $38 \%$ of students who study agricultural sciences, and $28 \%$ who study medicine do it for a fee but the most supported by the government are those who are enrolled into military service and security (they are almost entirely supported by the public budget).

Figure 6. The students dynamics at the first stage of study in the Republic of Moldova.

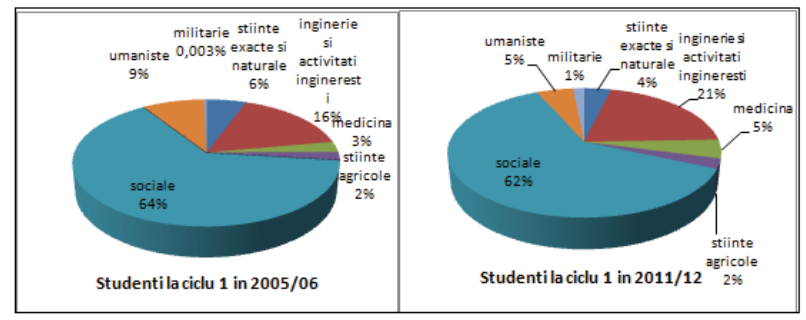

Source: elaborated by the authors according to NBS information.

Even the State's investments for education are explained, according to the increase of military and security students' number from Moldova in recent years is disturbing. The number of students at these specialties has increased during the past 5 years 3 times and reached from 470students to 1343. In the same time, the studies in natural and exact sciences have decreased with $2 \%$, but in absolute terms the decrease was manifested by a drop from 7105 students to 3306.

In these circumstances it should be reasonable to have an increasing number of students who tend to do their studies abroad, but at this chapter the growth is very moderate.

Figure 7. The comparative dynamics of students classification who are studying abroad. 


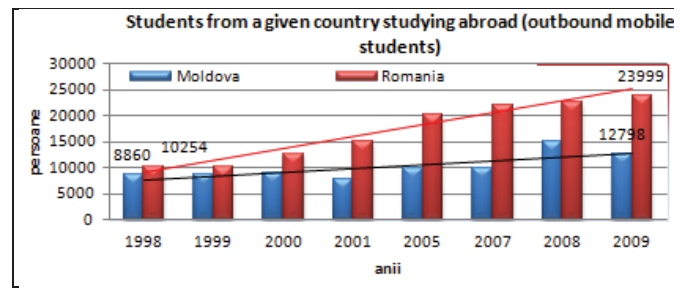

Source: elaborated by the authors according to UNESCO information.

The following data can let us see the comparison between Romania and Republic of Moldova for the period between 1998 - 2009. In comparison with Romania, the number of students who have gone abroad to study in the last twenty years, was 66\% lower than in the neighboring country. Since 1998 till 2009, the number of Romanian students who have gone to study abroad has doubled, while in Moldova this number increased much slower.

The process of studying of our citizens abroad has a larger scale than the attraction of foreign students in the universities of Moldova. The ratio is 7:1. According to NBS, "at the beginning of school year 2012/13, the number of foreign students accounted only two thousand people, that is 24.3 percent more students than in the previous year. The most of students are from Israel $-68.2 \%$, Ukraine $-8.1 \%$, Romania $-7.6 \%$, Russia $-5.0 \%$, Turkey - 3.0\%." These numbers represent an index that helps us to diagnosis the quality of our higher education.

\section{Concluding remarks}

In present, the Republic of Moldova faces a low level of investments in qualified human resources in qualified human resources. It cannot be identified a clearly oriented tendency regarding the public financing, but, there is an obvious shortfall in private key areas financing such as higher education and professional training.

For a good governance of university's educational system from Moldova it would be necessary to develop a strategy in which the main point would be reserved for attraction of private investments and to transparency of this process. However, according to the authors, our country should not focus itself on attracting private investments (in the form of fee payment which is made by students or their family members), but on attracting big investors. For example, the company that pays its employees contract in order to prepare highly qualified staff. In this case the investors will intend to invest only in a qualitative higher education, and from this point of view the universities will be required to improve the quality of their educational service.

Only such investors, who tend to prepare their own qualified staff and bring the profit to their own companies by implementing the received knowledge in practice, will develop to the maximum the sector of higher education.

Under the terms of an intense process of globalization and European integration combined with the background of a demographic disaster, the universities from the Republic of Moldova will undergo a process of an increased competition, which will generate the need to prepare and attract the greatest talents, to strengthen the entire system of the "knowledge triangle".

\section{References}

Turcan, A. (2013) Evaluarea economiei bazate pe cunoaştere. Revista „Economie şi sociologie”. Învăţămînt şi ştiinţă: http://www.statistica.md/category.php?|=ro\&idc=116\&\#idc=34\&

Educaţia în Republica Moldova: http://www.statistica.md/pageview.php?|=ro\&id=2819\&idc=350

UNESCO Institute for Statistics: http://data.un.org/Data.aspx?

UNESCO Institute for Statistics: http://stats.uis.unesco.org/unesco/TableViewer/tableView.aspx

Indicatorii educatiei: http://www.hse.ru/data/

Strategia „Educaţie şi Cercetare pentru Societatea Cunoaşterii” : http://www.presidency.ro/static/ordine/Educatie_si_Cercetare_pentru Societatea_Cunoasterii.pdf

Réformé des universités dans le cadre de la stratégie de Lisbonne: http://europa.eu/, http://europa.eu/legislation_summaries leducation_training

Clasamentului mondial Webometrics: http://www.webometrics.info/en/Europe/Moldova 